\title{
Efficacy of 5-day parenteral versus intramammary benzylpenicillin for treatment of clinical mastitis caused by gram-positive bacteria susceptible to penicillin in vitro
}

\author{
P. Kalmus,${ }^{\star 1}$ H. Simojoki, $†$ T. Orro, ${ }^{\star}$ S. Taponen, $†$ K. Mustonen, $†$ J. Holopainen, $\ddagger$ and S. Pyörälä† \\ *Department of Therapy, Institute of Veterinary Medicine and Animal Science, Estonian University of Life Sciences, Tartu, 51014, Estonia \\ †Department of Production Animal Medicine, Faculty of Veterinary Medicine, University of Helsinki, Paroninkuja 20, FI-04920 Saarentaus, Finland \\ ¥Thermo Fisher Scientific, FI-016210 Vantaa, Finland
}

\begin{abstract}
The efficacy of parenteral (intramuscular) or intramammary (IMM) benzylpenicillin treatment for clinical mastitis caused by gram-positive bacteria susceptible to penicillin in vitro was investigated. Cows with clinical mastitis in 1 udder quarter were randomly placed into 2 treatment groups. The preliminary bacteriological diagnosis of intramammary infection (IMI) was based on on-farm culturing, and the bacteriological diagnoses were later confirmed by a quantitative PCR assay. Clinical mastitis caused by gram-positive bacteria susceptible to benzylpenicillin was treated with penicillin via either the parenteral route $(20 \mathrm{mg} / \mathrm{kg})$ or IMM route $(600 \mathrm{mg})$ once per day for $5 \mathrm{~d}$. The outcome of the treatment was evaluated 3 to 4 wk after the onset of the treatment. The affected quarter was examined to assess the clinical cure, and milk samples were collected from the affected quarter to determine the bacteriological cure and milk N-acetyl- $\beta$-D-glucosaminidase activity. The survival and the composite milk somatic cell counts of the treated cows were followed up for 6 and 3 mo after treatment, respectively. A total of 140 cows with clinical mastitis were included in the study, 61 being treated with benzylpenicillin parenterally and 79 via the IMM route. From all quarters treated, 108 of $140(77.1 \%)$ were cured clinically and 77 of $140(55.0 \%)$ were cured bacteriologically. The route of treatment did not significantly affect the outcome of the treatment; $80.3 \%$ of the quarters with parenteral treatment and $74.7 \%$ of the quarters with IMM treatment showed a clinical cure, and 54.1 and $55.7 \%$ a bacteriological cure, respectively. The milk N-acetyl- $\beta$-D-glucosaminidase activity was significantly lower in the quarters with a clinical or bacteriological cure than in the quarters with no cure. The 6-mo survival and the proportion of cows with composite milk somatic cell counts $<200,000 / \mathrm{mL}$
\end{abstract}

Received August 5, 2013.

Accepted December 18, 2013.

${ }^{1}$ Corresponding author: piret.kalmus@emu.ee among the treated cows during the 3-mo follow-up period did not significantly differ between the treatment groups. In conclusion, the outcome of either parenteral or IMM benzylpenicillin treatment of clinical mastitis caused by penicillin-susceptible bacteria was similar.

Key words: dairy cow, clinical mastitis, treatment route, benzylpenicillin

\section{INTRODUCTION}

Bovine mastitis is the most common reason for the use of antimicrobials in dairy cows (Thomson et al., 2008). The most common route of administration for the treatment of mastitis is the intramammary (IMM) route (Gruet et al., 2001; Ruegg, 2010). Parenteral treatment of mastitis has been suggested to be more efficient than IMM treatment because of the improved distribution of the drug throughout the mammary gland (Ziv, 1980; Erskine et al., 2003). This would particularly apply to invasive infections, such as mastitis caused by Staphylococcus aureus (Erskine et al., 2003; Smith, 2010). Advantages of the IMM route over the parenteral route include high concentrations of the substance in the milk (Moretain and Boisseau, 1989; Smith, 2010) and lower consumption of the antimicrobial, because the dose of the drug directly infused into the quarter is small compared with parenteral treatment. A disadvantage of IMM treatment could be an uneven distribution of the antimicrobial to the upper parts of the affected quarter (Ehinger and Kietzmann, 2000) and risk for contamination when infusing the drug via the teat canal.

For the antimicrobial treatment of animal infections, such as mastitis, targeting the treatment toward the causative agents is recommended (OIE, 2013). If the causative agent of infection is susceptible to the so-called first-line antimicrobials, such as agents with a relatively narrow spectrum, including benzylpenicillin, they should be used for treatment (MAFF, 2003; Constable et al., 2008). However, in the majority of countries, the treatment of mastitis remains reliant on the routine use 
of combinations of several active substance or broadspectrum antimicrobials (Ruegg, 2010). Selection pressure for the development of antimicrobial resistance among bacteria is greater when broad-spectrum agents are used (Hunter et al., 2010). Parenteral treatment with benzylpenicillin has been the treatment of choice for clinical mastitis in Nordic countries (Grave et al., 1999; Thomson et al., 2008; Pyörälä, 2013). Thus far, studies comparing the outcome of parenteral and IMM treatment of clinical mastitis with benzylpenicillin have not been published. One Swedish study compared IMM and parenteral penicillin treatment with no treatment of subclinical mastitis and the bacteriological cure did not differ between the 2 antimicrobial treatment groups (Hallén Sandgren et al., 2008).

The gold standard to assess cure after treatment is bacteriological culturing, possibly completed with the determination of some indicator of inflammation in the milk, primarily the milk SCC (Green and Bradley, 2010; Ruegg, 2010). Other indicators of inflammation such as milk N-acetyl- $\beta$-D-glucosaminidase (NAGase) activity may also be used (Mattila and Sandholm, 1985). In addition, DNA-based bacteriological tests have become available for diagnostic use in bovine mastitis, providing an alternative to conventional culturing, and they are also useful for assessing bacteriological cure after antimicrobial treatment of mastitis (Koskinen et al., 2010). The objective of the study was to compare the outcome of parenteral and IMM treatment with benzylpenicillin in clinical mastitis caused by gram-positive bacteria susceptible to penicillin in vitro.

\section{MATERIALS AND METHODS}

\section{Characteristics of Study Herds}

The study was performed in 4 dairy herds in the practice area of the Large Animal Clinic of the Estonian University of Life Sciences (Tartu, Estonia) during 2007 to 2009. The study period was $1 \mathrm{yr}$ in each farm. The study was carried out in 2007 in 2 herds, in 2008 in 1 herd, and in 2009 in 1 herd. The herd size ranged from 300 to 1,000 dairy cows. All farms were loose-housing farms with a side-by-side milking parlor where the cows were milked 3 times per day. The average annual milk yield was $8,387 \mathrm{~kg}$ (minimum $=6,900 \mathrm{~kg}$; maximum $=$ $9,850 \mathrm{~kg}$ ). The mean herd bulk milk SCC per month ranged between 198,000 and 408,000 cells/mL during the study period.

\section{Collection and Analysis of Milk Samples}

Any lactating dairy cow with clinical mastitis was considered for enrollment in the study. Initial exclusion criteria were cows with more than 1 quarter affected and cows with known chronic mastitis, defined as cows with known high SCC or cows having had more than 3 mastitis episodes before the beginning of the study. Additionally, cows with a visible teat injury, and cows treated with antimicrobials within $1 \mathrm{wk}$ before the onset of clinical mastitis were excluded. Clinical mastitis was defined as any mastitis in which the cow showed visible, even mild, clinical signs (IDF, 1999). Before treatment, the cow was examined clinically and the results recorded on a study form. The clinical signs of the cow were assigned to the following 3 categories: (1) mild clinical mastitis $=$ changes in the milk appearance, in which the milk from the quarter had abnormal viscosity (watery or thicker than normal), abnormal color (yellow or blood tinged), or abnormal consistency (flakes or clots), but no udder swelling or systemic signs; (2) moderate clinical mastitis $=$ the same changes in the milk appearance and local signs in the quarter, such as swelling or pain, but no systemic signs, such as a lack of appetite, depressed rumen function, or body temperature greater than $39.2^{\circ} \mathrm{C}$; and (3) severe clinical mastitis $=$ both local and systemic signs.

\section{Handling of Milk Samples}

Clinical examination of the cows, sampling, and onfarm culturing were done by the local farm veterinarians. Before the study, all veterinarians were trained to collect aseptic milk samples and use on-farm culturing techniques. An aseptic milk sample was collected from the affected quarter before treatment. After discarding a few streams of milk, the samples $(5-7 \mathrm{~mL})$ were collected into sterile 10-mL plastic tubes. Approximately $2 \mathrm{~mL}$ of milk was separated for preliminary on-farm bacteriology and the remaining sample was stored at $-20^{\circ} \mathrm{C}$. All stored milk samples were submitted to the Thermo Fisher laboratory for DNA-based diagnosis (PathoProof mastitis PCR assay; Thermo Fisher Scientific, Vantaa, Finland) and to the laboratory of the Department of Production Animal Medicine, University of Helsinki (Saarentaus, Finland), for determination of milk NAGase activity.

\section{Bacteriological Culturing at the Farm}

Preliminary bacteriological examination was performed at the farm every evening using Tri-Plate selective mastitis agars, including blood-esculin agar, mannitol-salt agar, and MacConkey agar (Estonian Veterinary and Food Laboratory, Tartu, Estonia). The preliminary on-farm bacteriology was used to differentiate between gram-positive and gram-negative bacteria. Ten microliters of milk was streaked onto each sec- 
tion and plates were cultured for 12 to $24 \mathrm{~h}$. Bacterial growth was evaluated at first on the blood-esculin agar and then on the MacConkey agar (the media for detection of gram-negative bacteria) or on the salt-mannitol agar (the medium for detection of staphylococci). After detection of staphylococci, penicillin resistance, indicated by $\beta$-lactamase production, was determined using a chromogenic nitrocefin test (Becton Dickinson Microbiology Systems, Cockeysville, MD).

\section{Bacteriological Analysis Using Real-Time PCR Analysis}

Bacteriological diagnosis of mastitis was based on the PCR results. A commercial real-time PCR test kit (PathoProof mastitis PCR assay; Thermo Fisher Scientific) was used for direct analysis of all milk samples. The kit protocol involved 4 separate multiplex real-time PCR reactions, which targeted the following bacterial species and groups in total: Staphylococcus spp., including Staphylococcus aureus and all relevant CNS species; Enterococcus spp., including Enterococcus faecalis and Enterococcus faecium; Corynebacterium bovis; Escherichia coli; Streptococcus dysgalactiae; Streptococcus agalactiae; Streptococcus uberis; Trueperella (formerly Arcanobacterium) pyogenes/Peptoniphilus indolicus; Klebsiella spp., including Klebsiella oxytoca and Klebsiella pneumoniae; and Serratia marcescens. The PCR assay also detected the staphylococcal $\beta$-lactamase gene blaZ, coding for penicillin resistance. The assay was performed according to the manufacturer's instructions and as described by Koskinen et al. (2010). Based on the cycle threshold values, the bacterial DNA quantity in each targeted bacterial species was grouped into 3 classes: small $(+)$, intermediate $(++)$, or large $(+++)$ quantity.

\section{Milk NAGase Activity Determination}

Milk NAGase activity was determined with a fluorooptical method using an in-house microplate modification (Hovinen et al., 2010) of the method developed by Mattila and Sandholm (1985). The calibrated milk sample was replaced with a control milk sample with a known concentration of 4-methylumbelliferone (4-MU) and the NAGase activity was expressed as picomoles of $4-\mathrm{MU} / \mathrm{min}$ per microliter of milk at $25^{\circ} \mathrm{C}$. The upper detection limit for NAGase activity was $24.49 \mathrm{pmol}$ of $4-\mathrm{MU} / \mathrm{min}$ per microliter. Interassay and intraassay coefficients of variation for NAGase activity were 5 and $4 \%$, respectively.

\section{Treatments}

All cows with clinical mastitis were allocated into treatment groups $\mathrm{A}$ and $\mathrm{B}$ using cow ID $(\mathrm{A}=$ even numbers and $\mathrm{B}=$ odd numbers). The following 2 treatments were used: parenteral treatment with benzylpenicillin procaine (Penovet; vet $300 \mathrm{mg} / \mathrm{mL}$; Boehringer Ingelheim Vetmedica GmbH, Ingelheim, Germany) in group A and IMM treatment with benzylpenicillin procaine (Carepen; 600 mg; Vetcare Oy, Salo, Finland) in group B. One IMM tube was infused into the affected quarter once per day. The dose of benzylpenicillin used for parenteral treatment was $20 \mathrm{mg}$ (20,000 IU) per kilogram i.m. once per day. The duration of treatment was $5 \mathrm{~d}$ in both groups. The use of supportive treatment with nonsteroidal antiinflammatory agents (NSAID) was possible, but treatment with corticosteroids was not allowed. Treatment with penicillin according to the defined treatment groups began on the day of diagnosis. Treatment was stopped on the next day if gram-negative bacteria were detected on the selective media or if the isolated staphylococci were resistant to penicillin (a positive nitrocefin test). Cases of clinical mastitis caused by gram-negative bacteria were treated with NSAID, fluid therapy, and if the case was severe, with fluoroquinolones. Udder quarters infected with penicillin-resistant staphylococci were treated with IMM cloxacillin [Wedeclox mastitis; 1,000 mg of cloxacillin; Wirtschaftsgenossenschaft deutscher Tierärzte eG (WDT), Garbsen, Germany] once per day for $5 \mathrm{~d}$.

\section{Assessment of Treatment Outcome}

The outcome of the treatment was assessed 3 to $4 \mathrm{wk}$ after the onset of treatment by using clinical, inflammatory, and bacteriological criteria. The milk samples were collected as described above and frozen at $-20^{\circ} \mathrm{C}$. The cow was defined as clinically cured if the affected quarter was free from clinical signs. A quarter was defined as bacteriologically cured if the DNA of the same bacterial species detected in the pretreatment milk sample was not present in the follow-up milk sample. A quarter with the DNA from the same bacterial species detected before the treatment was defined as not cured.

Inflammatory reaction in the affected quarters was studied using milk NAGase activity, which should return back to normal after recovery from inflammation (Mattila and Sandholm, 1985). Milk NAGase activity was determined in the pretreatment and posttreatment milk samples, and used as an additional parameter to compare outcomes in the treatment groups (Hovinen et al., 2010).

Composite milk SCC (CMSCC) from the cows included in the study were collected from the study herds once each month during a 3-mo period after the treatment; the mean number of recordings per cow was 2.6. The culling data were analyzed during a 6 -mo period 
after the treatment. These data originated from the routine herd health recording system.

\section{The Final Enrollment Criteria}

Only cows with 1 affected udder quarter $(\mathrm{n}=140)$ with penicillin-susceptible, gram-positive bacteria were included in the study, based on the following criteria regarding the species detected by the PCR assay: (1) DNA of 1 bacterial species only, (2) DNA of 1 bacterial species in a proportion of over $99 \%$ of DNA from all target bacterial species detected, or (3) $>90 \%$ DNA of a major pathogen combined with a low quantity $(+)$ of DNA of a minor pathogen (CNS or C. bovis).

Polymerase chain reaction-negative samples $(\mathrm{n}=25)$, contaminated samples (more than 3 different species detected; $\mathrm{n}=27$ ), and samples containing DNA from gram-negative bacteria $(\mathrm{n}=11)$ were removed from the study. Cows $(\mathrm{n}=44)$ treated with IMM cloxacillin, and cows $(\mathrm{n}=26)$ with blaZ gene-positive staphylococcal species, but treated unintendedly with benzylpenicillin were excluded from the main material, but analyzed separately.

\section{Statistical Analysis}

Prior to the beginning of the study, the sample size necessary for statistical evaluation was calculated as 106 in both treatment groups. The calculations were based on the hypothesis that differences in the cure rates of the parenteral versus IMM treatment are less than 20\% (bacteriological cure rates of 65 and $45 \%$, respectively; 2 -sided $P$-value at 0.05 and a study power of $80 \%$ ). This hypothesis was based on the assumption that a large proportion of cases would be caused by Staph. aureus. However, after collection of the data, a large proportion of the cows were lost, due to missing data or post-inclusion exclusions, and the power of the study to detect at least a $20 \%$ difference in the bacteriological cure was $59 \%$ (sample size of 61 in the parenteral group and 79 in the IMM group).

Logistic regression models were used to evaluate the associations between clinical and bacteriological cures with treatment route. Bacteriological and clinical cures were the outcome variables. The treatment route (IMM or parenteral), bacteriological diagnosis as a 7-level categorical variable (Staph. aureus, CNS, Strep. agalactiae, Strep. dysgalactiae, Strep. uberis, C. bovis, and T. pyogenes), and the continuous variable milk NAGase activity in the pretreatment milk samples (as a marker of the severity of the inflammation) were included as independent variables. Additionally, the lactation number was used as a 4-level categorical variable (1, 2, 3, or $\geq 4$ lactations), the DIM was used as a 4-level categorized variable $(1-30,31-69,70-140$, or $>140$ DIM), and the farm and affected quarter were used as a 4-level variable. Nonsignificant variables were removed using a stepwise backward elimination procedure. The Wald test was used to evaluate the overall significance of the categorical variables with more than 2 levels. No significant interactions were detected and as no included variables were associated with any outcome variables, both final models included only treatment route as independent variable.

Differences in the number of culled cows between the treatment groups during the 6 mo after treatment were analyzed with a logistic model in which the treatment, farm, DIM, lactation number, and bacteriological diagnosis were included. Variables were categorized similarly to the previous models.

A linear regression model was used to investigate the associations between milk NAGase activity in the posttreatment milk samples and the route of treatment. Before analysis, the outcome variable milk NAGase activity was logarithmically transformed. The full models included bacteriological recovery (yes/ no), clinical recovery (yes/no), treatment route, diagnosed pathogens, and milk NAGase activity in clinical mastitis in the pretreatment milk samples, lactation number, DIM, farm, and affected quarter as fixed variables. The variables were categorized similarly to the previous logistic regression models. The Wald test was used to evaluate the overall significance of the categorical variables with more than 2 levels. Nonsignificant variables were removed using a stepwise backward elimination procedure. Possible interaction effects of the treatment with diagnosed clinical mastitis pathogens, bacteriological cure, clinical cure, and farm were verified. No significant interactions were detected. Assumptions of the model were controlled using normality and scatter plots of the model residuals. Stata 11.0 software (StataCorp LP, College Station, TX) was used for the logistic regression models and linear regression model.

For analyzing associations between the treatment and low CMSCC $(<200,000$ cells/mL) occurrence during the 21 to $110 \mathrm{~d}$ after the mastitis cases, a generalized linear mixed model was used. For this model, PROC GLIMMIX in the SAS/STAT 9.1 software (SAS Institute Inc., Cary, NC) was used. An autoregressive correlation structure was used for modeling serial correlations of repeated measurements within cows. Treatment, time group after mastitis $(21-50,51-80$, or 81-110 d), and their interaction, and sample time in relation to mastitis, DIM at the time of mastitis, and farm were included as fixed factors. 


\section{RESULTS}

\section{Outcome of Benzylpenicillin Treatment}

In total, 140 quarters with clinical mastitis were included in the study. Clinical signs were defined as mild in 83 cows $(59.2 \%)$ and moderate in 55 cows $(39.2 \%)$. Mastitis was defined as severe in 2 cows (1.4\%). Of 140 quarter cases with clinical mastitis, 61 (43.6\%) were treated with benzylpenicillin via the parenteral route and $79(56.4 \%)$ with benzylpenicillin via the IMM route. Distribution of the bacteria detected in the milk samples did not significantly differ between the treatment groups (Table 1). Streptococcus uberis was the most common bacteriological finding, followed by other streptococcal species.

No significant associations between the clinical cure [odds ratio $(\mathbf{O R})=1.38 ; 95 \%$ CI: $0.62-3.12 ; P=0.43$ ] or bacteriological cure $(\mathrm{OR}=0.94 ; 95 \% \mathrm{CI}$ : $0.48-1.83$; $P=0.85$ ) and the route of treatment were observed. The cure rates for the 140 quarters with clinical mastitis infected by gram-positive bacteria susceptible to benzylpenicillin in vitro are shown in Table 1.

Milk NAGase activities in the posttreatment samples did not differ between the 2 treatment groups $(P=0.69$; Table 2). Milk NAGase activity was significantly lower $(P=0.003)$ in the quarters with a clinical cure than the quarters with no clinical cure and in the bacteriologically cured quarters compared with those without bacteriological cure $(P=0.002$; Table 2$)$. The median NAGase activities in the milk before treatment and in the posttreatment samples are presented in Table 3.

In total, the number of culled cows was $18(13.1 \%)$ by the end of the 6-mo follow-up period after treatment. No data were available for 3 cows. No significant differences between the treatment groups (OR $=0.91 ; 95 \%$ CI: $0.33-2.46 ; P=0.51)$ were found.

\section{CMSCC After Treatment}

Individual-cow CMSCC data from 3 routine test milkings (every $30 \mathrm{~d}$ ) during the 3 -mo follow-up period after treatment were available for 126 cows. The summary of data and the proportion of cows with CMSCC $<200,000$ cells $/ \mathrm{mL}$ in the 2 treatment groups at different time points after treatment is shown in Table 4 . No association $(P=0.79)$ between the route of penicillin treatment and the proportion of cows with CMSCC $<200,000 / \mathrm{mL}$ after treatment was seen.

\section{DISCUSSION}

In this study, the outcome of benzylpenicillin treatment of clinical mastitis caused by gram-positive bacteria susceptible to penicillin in vitro was not affected by the route of administration of the drug. Clinical studies comparing the efficacy of parenteral and IMM treatment for clinical mastitis are, in general, rare. To our knowledge, field trials comparing the efficacy of parenteral and IMM benzylpenicillin treatment of bovine clinical mastitis have not been published. Parenteral penethamate hydroiodide treatment was compared with IMM penicillin-dihydrostreptomycin treatment in a study performed in New Zealand, and no significant differences were observed (McDougall, 1998). The majority of mastitis cases in that study were caused by Strep. uberis, a species susceptible to benzylpenicillin. Sérieys et al. (2005) compared treatment with parenteral penethamate to IMM ampicillincloxacillin, with no significant differences between the 2 treatment regimens. Specific information regarding the in vitro susceptibility of the causative agents was not available, and no real comparison can be made. In clinical mastitis experimentally induced by Strep. uberis and treated with penicillin, bacteriological cure

Table 1. The outcome of parenteral and intramammary 5-d treatment with benzylpenicillin of bovine clinical mastitis ( $\mathrm{n}=140$ quarters $)$ caused by gram-positive bacteria susceptible to benzylpenicillin in vitro

\begin{tabular}{|c|c|c|c|c|}
\hline Pathogen & \multicolumn{2}{|c|}{ Clinical cure } & \multicolumn{2}{|c|}{ Bacteriological cure } \\
\hline CNS $(\mathrm{n}=13)$ & $4 / 6$ & $6 / 7$ & $2 / 6$ & $4 / 7$ \\
\hline Streptococcus uberis $(\mathrm{n}=66)$ & $29 / 34$ & $22 / 32$ & $20 / 34$ & $16 / 32$ \\
\hline Streptococcus agalactiae $(\mathrm{n}=14)$ & $6 / 6$ & $6 / 8$ & $4 / 6$ & $6 / 8$ \\
\hline Trueperella pyogenes/Peptoniphilus indolicus $(\mathrm{n}=14)$ & $3 / 4$ & $8 / 10$ & $1 / 4$ & $2 / 10$ \\
\hline Total $(\mathrm{n}=140)^{3}(\%$ in parentheses $)$ & $49 / 61(80.3)$ & $59 / 79(74.7)$ & $33 / 61(54.1)$ & $44 / 79(55.7)$ \\
\hline
\end{tabular}


Table 2. Linear regression model of associations between milk N-acetyl- $\beta$-D-glucosaminidase (NAGase) activity in the posttreatment milk sample $(\mathrm{n}=140)$ and route (intramammary or parenteral) of treatment in clinical mastitis caused by gram-positive bacteria

\begin{tabular}{|c|c|c|c|c|}
\hline Variable & Estimate $^{1}$ & $95 \%$ CI & $P$-value & $\begin{array}{l}\text { Wald test } \\
(P \text {-value })\end{array}$ \\
\hline \multicolumn{5}{|l|}{ Treatment $^{2}$} \\
\hline IMM $(\mathrm{n}=79)$ & 0 & & & \\
\hline i.m. $(\mathrm{n}=61)$ & -0.08 & -0.44 to 0.26 & 0.69 & \\
\hline \multicolumn{5}{|l|}{ Bacteriological cure } \\
\hline No $(\mathrm{n}=63)$ & 0 & & & \\
\hline Yes $(\mathrm{n}=77)$ & -0.58 & -0.95 to -0.21 & 0.002 & \\
\hline \multicolumn{5}{|l|}{ Clinical cure } \\
\hline No $(\mathrm{n}=32)$ & 0 & & & \multirow{8}{*}{0.00} \\
\hline Yes $(\mathrm{n}=108)$ & -0.67 & -1.11 to -0.23 & 0.003 & \\
\hline Farm & & & & \\
\hline Farm $1(\mathrm{n}=17)$ & 0 & & & \\
\hline Farm $2(\mathrm{n}=11)$ & -0.28 & -1.12 to 0.55 & 0.51 & \\
\hline Farm $3(\mathrm{n}=66)$ & -1.01 & -1.67 to -0.47 & 0.001 & \\
\hline Farm $4(\mathrm{n}=46)$ & -0.13 & -0.81 to 0.43 & 0.54 & \\
\hline Intercept & 2.532 & 1.851 to 3.213 & 0.00 & \\
\hline
\end{tabular}

${ }^{1}$ Estimates are on a logarithmic scale.

${ }^{2} \mathrm{IMM}=$ intramammary treatment; i.m. = intramuscular treatment.

did not differ between IMM, parenteral, or combined treatment groups; however, the groups were so small that no conclusions could be made (Hillerton and Kliem, 2002). The dose of benzylpenicillin procaine used in that study was half of that used in our study, which could affect the parenteral cure rates. No differences between parenteral benzylpenicillin and IMM penethamate were found for the treatment of subclinical mastitis caused by penicillin-sensitive Staph. aureus or streptococci (Hallén Sandgren et al., 2008). In an old US study, the efficacy of IMM amoxicillin alone or combined with intramuscular benzylpenicillin was compared for the treatment of subclinical Staph. aureus mastitis (Owens et al., 1988). Bacteriological cure rates were approximately $50 \%$ and did not differ between the treatments; however, because no information regard- ing penicillin susceptibility was available, drawing any conclusions is difficult.

Overall, the bacteriological cure rates of clinical mastitis caused by staphylococci and streptococci treated with different antimicrobials and routes of administration have ranged from 56 to $84 \%$ (Jarp et al., 1989; Taponen et al., 2003a; Sérieys et al., 2005; McDougall et al., 2007; Apparao et al., 2009; Bradley and Green, 2009; Ruegg, 2010). Taponen et al. (2003a) used a 4-d treatment with IMM benzylpenicillin for mastitis caused by penicillin-susceptible, gram-positive bacteria and reported a clinical cure rate of $75 \%$ and a bacteriological cure rate of $73 \%$. The clinical cure rate was similar to our study, but the bacteriological cure rate was approximately $20 \%$ higher than in the present study, which may be due to the different clinical severity of

Table 3. Milk N-acetyl- $\beta$-D-glucosaminidase (NAGase) activity in milk samples from quarters with clinical or bacteriological cure or no cure $(\mathrm{n}=140)$ before and after 5 -d parenteral or intramammary penicillin treatment of clinical mastitis caused by gram-positive bacteria

\begin{tabular}{|c|c|c|}
\hline \multirow[b]{2}{*}{ Item } & \multicolumn{2}{|c|}{$\begin{array}{l}\text { Median milk NAGase activity } \\
(\text { pmol of } 4-\mathrm{MU} / \mathrm{min} \text { per microliter })^{1}\end{array}$} \\
\hline & Before treatment & After treatment \\
\hline \multicolumn{3}{|l|}{ Clinical cure } \\
\hline Yes $(\mathrm{n}=108)$ & $24.18(0.53 ; 24.49)$ & $2.73(0.75 ; 24.29)$ \\
\hline No $(\mathrm{n}=32)$ & $17.17(1.49 ; 24.49)$ & $5.84(0.59 ; 24.49)$ \\
\hline \multicolumn{3}{|c|}{ Bacteriological cure } \\
\hline Yes $(\mathrm{n}=77)$ & $17.58(1.49 ; 24.49)$ & $2.44(0.15 ; 24.49)$ \\
\hline No $(\mathrm{n}=63)$ & $24.49(0.53 ; 24.49)$ & $3.41(0.16 ; 24.49)$ \\
\hline \multicolumn{3}{|l|}{ Treatment $^{2}$} \\
\hline i.m. $(\mathrm{n}=61)$ & $24.49(1.22 ; 24.49)$ & $2.32(0.15 ; 24.49)$ \\
\hline IMM (n = 79) & $20.53(0.53 ; 24.49)$ & $3.12(0.16 ; 24.49)$ \\
\hline
\end{tabular}


Table 4. Individual-cow composite milk SCC (CMSCC) and proportions of cows with CMSCC $<200,000$ cells/mL collected during a 3-mo period $(21-110 \mathrm{~d})$ after parenteral or intramammary penicillin treatment of clinical mastitis caused by gram-positive bacteria

\begin{tabular}{|c|c|c|c|c|}
\hline \multirow{2}{*}{$\begin{array}{l}\text { Period }(\mathrm{d}) \text { after } \\
\text { clinical mastitis } \\
\text { and treatment }^{1}\end{array}$} & \multicolumn{2}{|c|}{ Individual cow CMSCC (cells/mL) } & \multirow{2}{*}{$\begin{array}{c}\text { Proportion of samples } \\
\text { with CMSCC below } \\
200,000 \text { cells/mL (\%) }\end{array}$} & \multirow[b]{2}{*}{$P$-value } \\
\hline & Mean $( \pm \mathrm{SD})$ & Median (minimum; maximum) & & \\
\hline i.m. $(\mathrm{n}=59)$ & $456,400( \pm 649,800)$ & $194,000(17,000 ; 3,287,000)$ & 50.8 & \\
\hline $\operatorname{IMM}(\mathrm{n}=70)$ & $851,246( \pm 1,332,200)$ & $260,000(5,000 ; 7,073,000)$ & 39.6 & \\
\hline $51-80 \mathrm{~d}$ & & & & 0.31 \\
\hline i.m. $(\mathrm{n}=49)$ & $408,604( \pm 526,540)$ & $210,000(11,000 ; 2,384,000)$ & 47.4 & \\
\hline i.m. $(\mathrm{n}=46)$ & $670,100( \pm 1,175,300)$ & $256,500(8,000 ; 6,062,000)$ & 43.2 & \\
\hline $\operatorname{IMM}(\mathrm{n}=53)$ & $648,900( \pm 1,251,200)$ & $195,000(10,000 ; 8,272,000)$ & 50.6 & \\
\hline
\end{tabular}

${ }_{1}$ i.m. = intramuscular treatment; IMM = intramammary treatment.

mastitis or different methods used for the bacteriological follow-up. Jarp et al. (1989) reported a total bacteriological cure rate of $68 \%$ for clinical mastitis due to gram-positive, penicillin-susceptible bacteria, treated for $5 \mathrm{~d}$ with benzylpenicillin, using the same dose as in the current study. The cure rate of that study was also higher than reported in our study, possibly due to the same reasons as mentioned earlier. Bacteriological cure rates of mastitis depend on the causative agent. McDougall et al. (2007) compared treatment of clinical mastitis with 3 different IMM products, one of them containing procaine penicillin alone. More than half of the cases were caused by Strep. uberis and treatment with penicillin IMM for $1.5 \mathrm{~d}$ resulted in a cure rate as high as $91 \%$, which is much higher than found here. Different conditions in the New Zealand, such as much lower average milk production and less severe clinical signs, may at least partly explain the difference.

Mastitis-causing streptococcal species have remained susceptible to benzylpenicillin (Pitkälä et al., 2004; Hendriksen et al., 2008; Bengtsson et al., 2009; Kalmus et al., 2011). Staphylococcus aureus and CNS isolated from bovine mastitis have developed resistance to penicillin (Hendriksen et al., 2008; Bagcigil et al., 2012), which may significantly influence the efficacy of treatment (Pyörälä and Pyörälä 1998; Sol et al.; 2000; Taponen et al., 2003b). In our study, 6 of 8 cases of mastitis caused by penicillin-susceptible Staph. aureus were cured using either intramuscular or IMM penicillin treatment. The bacteriological cure of 20 quarters with mastitis caused by penicillin-resistant Staph. aureus treated for $5 \mathrm{~d}$ with cloxacillin was in the present study zero (data not shown). It is known that mastitis caused by penicillinresistant Staph. aureus is difficult to cure (Taponen et al., 2003b; Barkema et al., 2006). The poor treatment response of these cases is mainly not derived from antibiotic resistance. The ability of penicillin-resistant Staph. aureus isolates to cause persistent infections may be due to several virulence factors, possibly linked to the $\beta$-lactamase gene of the resistant isolates (Haveri et al., 2005; van den Borne et al., 2010). In the treatment of mastitis, tested or assumed in vitro susceptibility of the causing bacteria is considered a prerequisite for the use of a particular antibiotic, but pretreatment susceptibility is not always predictive of treatment response in vivo (Barlow, 2011).

Benzylpenicillin is a weak acid, which, after parenteral administration, penetrates poorly into the mammary gland. However, because the minimum inhibitory concentration values for susceptible organisms are generally very low $(\leq 0.12 \mu \mathrm{g} / \mathrm{mL}$ for staphylococci and $\leq 0.06 \mu \mathrm{g} / \mathrm{mL}$ for streptococci; Prescott, 2007; Bengtsson et al., 2009), it is possible to achieve and maintain therapeutic concentrations in the milk using parenteral administration of $20 \mathrm{mg}$ of benzylpenicillin procaine $/ \mathrm{kg}$ once per day as used in the current study (Franklin et al., 1984; Ziv and Storper, 1985).

Intramammary infusion results in concentrations as high as 100- to 1,000-fold of those obtained with parenteral administration, which is advantageous for infections of the milk compartment, such as streptococcal mastitis (Moretain and Boisseau, 1989; Erskine et al., 2003). The total dose of antimicrobials administered via the IMM route is considerably lower than that in parenteral treatment. Furthermore, painful injections can be avoided. When infusing IMM containing narrow-spectrum antimicrobials antibiotics such as benzylpenicillin, strict hygienic measures should be used to avoid inducing mastitis (Middleton and Luby, 2008). Intramammary administration is the route of choice for mastitis caused by streptococcal species, which reside in the milk compartment (Erskine et al., 2003). Parenteral or combined treatment has been suggested for mastitis caused by Staph. aureus (Erskine et al., 2003; Constable et al., 2008). Taponen et al. (2003b) reported a bacteriological cure of $72 \%$ for mastitis caused by penicillinsusceptible Staph. aureus treated with 5-d combined parenteral and IMM treatment with penicillin. In our 
study, no difference was observed between the 2 routes of treatment, but the Staph. aureus group was too small to draw any conclusions. Our group infected with CNS was also small, but based on the literature, IMM is the route of choice in the treatment of CNS mastitis (Erskine et al., 2003; Pyörälä and Taponen, 2009).

In this study, bacteriological diagnosis was based on a PCR assay. For the evaluation of the bacteriological cure, strict criteria were used. If DNA of the same species detected before treatment was found alone or together with the DNA of other species in the posttreatment sample, the case was classified as not cured. It is known that the PCR-based assay is more sensitive than conventional culture (Koskinen et al., 2010). This may be reflected as lower percentages of cure than in previous studies in which conventional culturing was used for assessment. Excluding all samples with more than 1 species from the analysis would result in the discarding of a considerable number of cases, because the PCR test often detects more than 1 species (Koskinen et al., 2010).

Higher cure rates may have also been expected here because our 5 -d treatment was longer than standard treatments used for mastitis in many countries. Longer treatments have been reported to result in higher cure rates, at least for mastitis caused by Staph. aureus and Strep. uberis (Jarp et al., 1989; Oliver et al., 2004; Deluyker et al., 2005; Krömker et al., 2010). Recently, 5 -d treatment with cefquinome did not increase cure rates in clinical Staph. aureus mastitis compared with 1.5-d treatment (Swinkels et al., 2013). This discrepant result may be due to the drug used or differences in the virulence of the bacterial strains causing IMI.

In assessing cure rates, the possibility of contamination of the sample with the same species as detected in the pretreatment sample should also to be taken into account. This could lead to a false-positive sample and false classification of the case as not cured. However, this affects both conventional and PCR-based tests. If PCR assays are used to assess the outcome in treatment trials of mastitis, some adjustments to the tests may be necessary for the interpretation of results.

Combining bacteriology with some indicator of inflammation in the milk would be useful for confirming the assessment (Green and Bradley, 2010). The most common indicator used to monitor the inflammatory status of the udder is milk SCC. Milk NAGase activity is another good choice for this purpose (Pyörälä, 2003). $\mathrm{N}$-Acetyl- $\beta$-D-glucosaminidase originates from somatic cells but also from damaged epithelial cells (Mattila and Sandholm, 1985; Pyörälä, 2003). It correlates well with milk SCC and has the advantage that freezing the milk samples does not interfere with the analysis (Pyörälä, 2003). The threshold values of these param- eters should perhaps be adjusted for the assessment of the response to mastitis treatment, because the inflammatory reaction of the quarter may last longer than elimination of the infection. The threshold levels of the markers used for screening of mastitis may be too high for monitoring the recovery of the quarter (Pyörälä and Pyörälä, 1997).

Generally, 2 posttreatment samples are recommended for the bacteriological evaluation of cure (Schukken and Deluyker, 1995). Here, only 1 sample was collected for practical reasons, but we used a sensitive PCR assay for bacteriology, which could somewhat compensate for the lack of the second sampling. Including the cow survival data and cow composite milk SCC follow-up provides information regarding the long-term effects of the treatments and can be recommended for field trials of mastitis. In the present study, the CMSCC remained higher and the proportion of low-CMSCC cows was numerically smaller in the IMM-treated group, even though no significant differences between the groups were found. A possible explanation for this result is that the cows had other quarters with subclinical IMI, which were also treated when the treatment was administered parenterally and this may have affected cow CMSCC.

\section{CONCLUSIONS}

The outcome of parenteral or IMM penicillin treatment of mastitis caused by penicillin-susceptible bacteria was found to be similar. We conclude that IMM could routinely be used for the treatment of clinical mastitis caused by streptococcal species. Streptococci reside in the milk compartment and no pharmacokinetic grounds exist for the use of parenteral administration of the antimicrobial. Parenteral treatment is more invasive and significantly increases the dose of the antimicrobial. The number of quarters infected with Staph. aureus was too low to reach any conclusions regarding treatment of Staph. aureus mastitis. With a more sensitive PCR method, bacteriological cure rates may be lower, which should be considered by researchers, the pharmaceutical industry, and authorities in the future.

\section{ACKNOWLEDGMENTS}

This work was funded by grants from the Walter Ehrström Foundation (Helsinki, Finland), Finnish Dairy Association (Helsinki, Finland), Finnish Veterinary Foundation, and the Research Foundation of Veterinary Medicine (Helsinki, Finland). We thank Vetcare Oy (Salo, Finland) for kindly providing the medicinal preparations. Additional financial support was provided by the Estonian Ministry of Agriculture (Tallinn, 
Estonia; research contract 8-2/T8010) and the Estonian Ministry of Education (Tartu, Estonia; research project 8-2/T9001). Invaluable help of personnel from participating farms is deeply appreciated.

\section{REFERENCES}

Apparao, M. D., P. L. Ruegg, A. Lago, S. Godden, R. Bey, and K. Leslie. 2009. Relationship between in vitro susceptibility test results and treatment outcomes for gram-positive mastitis pathogens following treatment with cephapirin sodium. J. Dairy Sci. 92:2589-2597.

Bagcigil, A. F., S. Taponen, J. Koort, B. Bengtsson, A.-L. Myllyniemi, and S. Pyörälä. 2012. Genetic basis of penicillin resistance of $S$. aureus isolated in bovine mastitis. Acta Vet. Scand. 54:69.

Barkema, H. W., Y. H. Schukken, and R. N. Zadoks. 2006. Invited review: The role of cow, pathogen, and treatment regimen in the therapeutic success of bovine Staphylococcus aureus mastitis. J. Dairy Sci. 89:1877-1895.

Barlow, J. 2011. Mastitis therapy and antimicrobial susceptibility: A multispecies review with a focus on antibiotic treatment of mastitis in dairy cattle. J. Mammary Gland Biol. Neoplasia 16:383-407.

Bengtsson, B., H. Ericsson Unnerstad, T. Ekman, K. Artursson, M. Nilsson-Öst, and K. Persson Waller. 2009. Antimicrobial susceptibility of udder pathogens from cases of acute clinical mastitis in dairy cows. Vet. Microbiol. 136:142-149.

Bradley, A. J., and M. J. Green. 2009. Factors affecting cure when treating bovine clinical mastitis with cephalosporin-based intramammary preparation. J. Dairy Sci. 92:1941-1953.

Constable, P., S. Pyörälä, and G. Smith. 2008. Guidelines for antimicrobial use in cattle. Pages 143-160 in Guide to Antimicrobial Use in Animals. L. Guardabassi, L. B. Jensen, and H. Kruse, ed. Blackwell Publishing Ltd., Oxford, UK.

Deluyker, H. A., S. N. van Oye, and J. F. Boucher. 2005. Factors affecting cure and somatic cell count after pirlimycin treatment of subclinical mastitis in lactating cows. J. Dairy Sci. 88:604-614.

Ehinger, A. M., and M. Kietzmann. 2000. Tissue distribution of benzylpenicillin after intramammary administration in the isolated perfused bovine udder. J. Vet. Pharmacol. Ther. 23:303-310.

Erskine, R. J., S. Wagner, and F. J. DeGraves. 2003. Mastitis therapy and pharmacology. Vet. Clin. North Am. Food Anim. Pract. 19:109.

Franklin, A., O. Holmberg, M. Horn af Rantzien, and G. Åström. 1984. Effect of procaine benzylpenicillin alone or in combination with dihydrostreptomycin on udder pathogens in vitro and in experimentally infected bovine udders. Am. J. Vet. Res. 45:1398-1402.

Grave, K., C. Greko, L. Nilsson, K. Odensvik, T. Mørk, and M. Rønning. 1999. The usage of veterinary antibacterial drugs for mastitis in cattle in Norway and Sweden during 1990-1997. Prev. Vet. Med. 42:45-55.

Green, M., and A. Bradley. 2010. Practical methods to evaluate treatment outcomes. Pages 131-140 in Proc. National Mastitis Council 49th Annual Meeting, Albuquerque, NM. National Mastitis Council, Madison, WI.

Gruet, P., P. Maincent, X. Berthelot, and V. Kaltsatos. 2001. Bovine mastitis and intramammary drug delivery: Review and perspectives. Adv. Drug Deliv. Rev. 50:245-259.

Hallén Sandgren, C., K. Persson Waller, and U. Emanuelson. 2008. Therapeutic effects of systemic or intramammary antimicrobial treatment of bovine subclinical mastitis during lactation. Vet. J. 175:108-117.

Haveri, M., A. Roslöf, L. Rantala, and S. Pyörälä. 2005. Toxin genes of Staphylococcus aureus isolated from bovine intramammary infection of different clinical characteristics and outcome. Pages 149154 in Proc. 4th IDF International Mastitis Conference. Mastitis in Dairy Production. Current Knowledge and Future Solutions, Maastricht, the Netherlands. Wageningen Academic Publishers, Wageningen, the Netherlands.
Hendriksen, R. S., D. J. Mevius, A. Schroeter, C. Teale, D. Meunier, P. Butaye, A. Franco, A. Utinane, A. Amado, M. Moreno, C. Greko, K. Stärk, C. Berghold, A.-L. Myllyniemi, D. Wasyl, M. Sunde, and F. M. Aarestrup. 2008. Prevalence of antimicrobial resistance among bacterial pathogens isolated from cattle in different European countries: 2002-2004. Acta Vet. Scand. 50:28.

Hillerton, J. E., and K. E. Kliem. 2002. Effective treatment of Streptococcus uberis clinical mastitis to minimize the use of antibiotics. J. Dairy Sci. 85:1009-1014.

Hovinen, M., H. Simojoki, R. Pösö, J. Suolaniemi, and S. Pyörälä. 2010. N-Acetyl- $\beta$-D-glucosaminidase activity in normal cow milk. Page 16 in Proc. 8th European Colloquium on Acute Phase Proteins, Helsinki, Finland.

Hunter, P. A., S. Dawson, G. L. French, H. Goossens, P. M. Hawkey, E. J. Kuijper, D. Nathwani, D. J. Taylor, C. J. Teale, R. E. Warren, M. H. Wilcox, N. Woodford, M. W. Wulf, and L. J. V. Piddock. 2010. Antimicrobial-resistant pathogens in animals and man: Prescribing, practices and policies. J. Antimicrob. Chemother. 65(Suppl. 1):i3-i17.

IDF (International Dairy Federation). 1999. Suggested interpretation of mastitis terminology. Bull. Int. Dairy Fed. 338:3-26.

Jarp, J., H. P. Bugge, and S. Larsen. 1989. Clinical trial of three therapeutic regimens for bovine mastitis. Vet. Rec. 17:630-634.

Kalmus, P., B. Aasmäe, A. Kärssin, T. Orro, and K. Kask. 2011. Udder pathogens and their resistance to antimicrobial agents in dairy cows in Estonia. Acta Vet. Scand. 53:4.

Koskinen, M. T., G. J. Wellenberg, O. C. Sampimon, J. Holopainen, A. Rothkamp, L. Salmikivi, W. A. van Haeringen, T. J. G. M. Lam, and S. Pyörälä. 2010. Field comparison of real-time polymerase chain reaction and bacterial culture for identification of bovine mastitis bacteria. J. Dairy Sci. 93:5707-5715.

Krömker, V., J. H. Paduch, D. Klocke, J. Friedrich, and C. Zinke. 2010. Efficacy of extended intramammary therapy to treat moderate and severe clinical mastitis in lactating dairy cows. Berl. Munch. Tierärztl. Wochenschr. 123:147-152.

MAFF (Ministry of Agriculture and Forestry). 2003. Use of antimicrobial agents in animals. Report of the working group on antimicrobial agents. MAFF Publications 9. MAFF, Helsinki, Finland.

Mattila, T., and M. Sandholm. 1985. Antitrypsin and N-acetyl- $\beta-D-$ glucosaminidase as markers of mastitis in herd of Ayshire cows. Am. J. Vet. Res. 46:2453-2456.

McDougall, S. 1998. Efficacy of two antibiotic treatments in curing clinical and subclinical mastitis in lactating dairy cows. N. Z. Vet. J. $46: 226-232$.

McDougall, S., D. G. Arthur, M. A. Bryan, J. J. Vermunt, and A. M. Weir. 2007. Clinical and bacteriological response to treatment of clinical mastitis with one of three intramammary antibiotics. $\mathrm{N}$. Z. Vet. J. 55:161-170.

Middleton, J. R., and C. D. Luby. 2008. Escherichia coli mastitis in cattle being treated for Staphylococcus aureus intramammary infection . Vet. Rec. 162:156-157.

Moretain, J. P., and J. Boisseau. 1989. Excretion of penicillins and cephalexin in bovine milk following intramammary administration. Food Addit. Contam. 6:79-89.

OIE (World Organisation for Animal Health). 2013. Responsible and prudent use of antimicrobial agents in veterinary medicine. Accessed Oct. 2013. http://www.oie.int/index.php?id=169\&L=0\&h tmfile=chapitre_1.6.9.htm.

Oliver, S. P., B. E. Gillespie, S. J. Headrick, H. Moorehead, P. Lunn, H. H. Dowlen, D. L. Johnson, K. C. Lamar, S. T. Chester, and W. M. Moseley. 2004. Efficacy of extended ceftiofur intramammary therapy for treatment of subclinical mastitis in lactating dairy cows. J. Dairy Sci. 87:2393-2400.

Owens, W. E., J. L. Watts, R. L. Boddie, and S. C. Nickerson. 1988. Antibiotic treatment of mastitis: Comparison of intramammary and intramammary plus intramuscular therapies. J. Dairy Sci. 71:3143-3147.

Pitkälä, A., M. Haveri, S. Pyörälä, V. Myllys, and T. Honkanen-Buzalski. 2004. Bovine mastitis in Finland 2001-Prevalence, distribution of bacteria, and antimicrobial resistance. J. Dairy Sci. $87: 2433-2441$. 
Prescott, J. F. 2007. Beta-lactam antibiotics: Penam penicillins. Pages 121-137 in Antimicrobial Therapy in Veterinary Medicine. 4th ed. S. Giguère, J. F. Prescott, J. D. Baggot, R. D. Walker, and P. M. Dowling, ed. Blackwell Publishing Ltd., Oxford, UK.

Pyörälä, S. 2003. Indicators of inflammation in the diagnosis of mastitis. Vet. Res. 34:565-578.

Pyörälä, S. 2013. Treatment of bovine mastitis-Nordic principles. Page 29 in Proc. 29th NKVet Mastitis Symposium, Reykjavik, Iceland. The Nordic Commitee for Veterinary Scientific Cooperation, Reyikjavik, Iceland.

Pyörälä, S., and E. Pyörälä. 1997. Accuracy of methods using somatic cell count and milk N-acetyl- $\beta$-D-glucosaminidase activity in milk to assess the bacteriological cure of bovine clinical mastitis. J. Dairy Sci. 80:2820-2825.

Pyörälä, S. H., and E. O. Pyörälä. 1998. Efficacy of parenteral administration of three antimicrobial agents in treatment of clinical mastitis in lactating cows: 487 cases (1989-1995). J. Am. Vet. Med. Assoc. 212:407-412.

Pyörälä, S., and S. Taponen. 2009. Coagulase-negative staphylococciEmerging mastitis pathogens. Vet. Microbiol. 134:3-8.

Ruegg, P. L. 2010. The application of evidence based veterinary medicine to mastitis therapy. Pages $78-93$ in Proc. Updates on Ruminant Production and Medicine XXVI World Buiatrics Congress, Santiago, Chile. Chilean Buiatric Society, Santiago, Chile.

Schukken, Y. H., and H. A. Deluyker. 1995. Design of field trials for the evaluation of antibacterial products for therapy of bovine clinical mastitis. J. Vet. Pharmacol. Ther. 18:274-283.

Sérieys, F., Y. Raguet, L. Goby, H. Schmidt, and G. Friton. 2005. Comparative efficacy of local and systemic antibiotic treatment in lactating cows with clinical mastitis. J. Dairy Sci. 88:93-99.

Smith, G. W. 2010. The pharmacologic aspects of mastitis treatment Pages 98-108 in National mastitis Council Annual Meeting Proceedings. Nat. Mastitis Counc. Inc., Madison, WI.
Sol, J., O. C. Sampimon, H. W. Barkema, and Y. H. Schukken. 2000 Factors associated with cure after therapy of clinical mastitis caused by Staphylococcus aureus. J. Dairy Sci. 83:278-284.

Swinkels, J. M., P. Cox, Y. H. Schukken, and T. J. G. H. Lam. 2013. Efficacy of extended cefquinome treatment of clinical Staphylococcus aureus mastitis. J. Dairy Sci. 96:4983-4992.

Taponen, S., K. Dredge, B. Henriksson, A.-M. Pyyhtiä, L. Suojala, R. Junni, K. Heinonen, and S. Pyörälä. 2003a. Efficacy of intramammary treatment with procaine penicillin $G$ vs. procaine penicillin plus neomycin in bovine clinical mastitis caused by penicillin-susceptible, gram-positive bacteria - A double blind field study. J. Vet. Pharmacol. Ther. 26:193-198.

Taponen, S., A. Jantunen, E. Pyörälä, and S. Pyörälä. 2003b. Efficacy of targeted 5-day parenteral and intramammary treatment of clinical mastitis caused by penicillin-susceptible or penicillin-resistant Staphylococcus aureus. Acta Vet. Scand. 44:53-62.

Thomson, K., M. Rantala, M. Hautala, S. Pyörälä, and L. Kaartinen. 2008. Cross-sectional prospective survey to study indication-based usage of antimicrobials in animals: Results of use in cattle. BMC Vet. Res. 4:15.

van den Borne, B. H. P., M. Nielen, M. M. van Schaik, M. B. Melchior, T. J. G. M. Lam, and R. N. Zadoks. 2010. Host adaptation of bovine Staphylococcus aureus seems associated with bacteriological cure after lactational antimicrobial treatment. J. Dairy Sci. 93:2550-2558.

Ziv, G. 1980. Drug selection and use in mastitis: Systemic vs local therapy. J. Am. Vet. Med. Assoc. 176:1109-1115.

Ziv, G., and M. Storper. 1985. Intramuscular treatment of subclinical staphylococcal mastitis in lactating cows with penicillin G, methicillin and their esters. J. Vet. Pharmacol. Ther. 8:276-283. 